\title{
Makna Simbol dalam Aesan Gede dan Pak Sangkong Pakaian Adat Pernikahan Palembang
}

\author{
Eka Hikmawati \\ Fakultas Adab dan Humaniora \\ Universitas Islam Negeri Raden Fatah Palembang \\ E-mail: ekahikmawati_uin@radenfatah.ac.id
}

\begin{abstract}
Abstrak
Budaya menjadi salah satu dasar dari setiap kehidupan manusia, karena kebudayaan adalah sesuatu yang mutlak dimiliki manusia. Pakaian merupakan salah satu hasil karya manusia dalam masyarakat yang bersifat konkret dan merupakan benda yang dapat diraba, dilihat dan difoto. Pakaian lebih mengarah kepada hasil karya yang berasal dari sistem budaya. Karena, pakaian yang hingga saat ini dikenal merupakan hasil pemikiran, gagasan dan konsep baik seseorang maupun sekelompok yang hidup dalam sebuah lingkungan budaya. Palembang mempunyai beberapa pakaian adat yaitu diantaranya, aesan gede dan pak sangkong. Aesan gede dan pak sangkong ini merupakan pakaian adat yang dipakai oleh pengantin ketika acara resepsi atau saat upacara adat pernikahan di Palembang yaitu, penganten munggah. Pakaian adat pernikahan ini mendapat pengaruh dari budaya asing yang tetap eksis di Palembang dari masa Sriwijaya, Kerajaan Palembang hingga masa Kesultanan Palembang Darussalam sampai pada masa kini. Pakaian adat Palembang ini dibagi menjadi dua yaitu pakaian utama dan ada yang disebut pelengkap Pakaian. Perpaduan budaya Jawa, Cina dan Arab pada aesan gede dan pak sangkong tidak menghilangkan kebudayaan asli di Palembang ini merupakan hasil dari akulturasi budaya. Serta, banyak makna simbol yang terkandung pada pakaian adat pernikahan Palembang ini yang kesemuanya memiliki pesan yang luhur untuk kebaikan dunia dan akhirat.
\end{abstract}

Kata Kunci: Aesan Gede, Pak Sangkong, Pakaian Adat

Indonesia merupakan negara yang memiliki berbagai macam suku, etnis, bahasa, agama dan adat istiadat yang semuanya merupakan cerminan dari kemajemukan bangsa. Adat mempunyai ikatan dan pengaruh yang kuat dalam masyarakat dan kekuatan yang mengikatnya tergantung pada masyarakat tersebut. Kebudayaan bangsa Indonesia merupakan warisan dari nenek moyang dahulu yang merupakan gabungan dari beberapa unsur kebudayaan daerah, kebudayaan daerah merupakan wujud dari kebudayaan nasional. Kebudayaan daerah tercermin dalam berbagai aspek kehidupan masyarakat di seluruh daerah di Indonesia. Setiap daerah memiliki ciri khas kebudayaan yang berbeda, baik dari hasil karya masyarakat maupun hasil kebudayaan yang meliputi rumah adat, tarian, lagu, alat musik, pakaian dan sebagainya (Rosyadi, 2012: 2).

Istilah "kebudayaan" dan "culture" berasal dari bahasa Sanskerta buddhayah, yang merupakan bentuk jamak dari kata buddhi yang berarti budi atau akal. Sementara itu, kata culture berasal dari kata Latin colere, yaitu mengolah atau mengerjakan. Koentjaraningrat mendefinisikan kebudayaan sebagai seluruh sistem gagasan dan rasa, tindakan serta karya yang dihasilkan manusia dalam kehidupan bermasyarakat, yang dijadikan miliknya dengan belajar (Koentjaraningrat, 1996: 72-73). Kebudayaan adalah 
simbol yang berarti hasil olahan pikir yang memungkinkan untuk mengodekan atau membukakan kode dari sesuatu yang hadir di hadapan kita, seperti pada contoh air suci pada kelompok Katolik.

Selanjutnya, Koentjaraningrat dalam bukunya Pengantar Antropologi I, menyatakan agar kebudayaan dibeda-bedakan sesuai dengan empat wujudnya yaitu: 1) Melambangkan kebudayaan sebagai benda-benda fisik yang merupakan wujud konkret dari kebudayaan; 2) Melambangkan kebudayaan sebagai sistem tingkah laku dan tindakan berpola; 3) Melambangkan kebudayaan sebagai sistem gagasan; dan 4) Melambangkan kebudayaan sebagai sistem gagasan yang ideologis.

Dari wujud kebudayaan yang terurai di atas yaitu yang berupa wujud sistem budaya, sistem sosial dan kebudayaan fisik ini terdapat pada tiap-tiap unsur kebudayaan yaitu bahasa, sistem pengetahuan, organisasi sosial, sistem peralatan hidup dan teknologi, sistem mata pencarian hidup, sistem religi, kesenian (Koentjaraningrat, 1996: 74-80).

Dari pengertian dan uraian di atas, maka pakaian dapat dikategorikan sebagai budaya fisik karena merupakan hasil dari karya manusia dalam masyarakat yang bersifat konkret dan merupakan benda yang dapat diraba, dilihat dan difoto. Namun, karya itu lebih mengarah kepada hasil karya yang berasal dari sistem budaya. Karena, pakaian yang hingga saat ini dikenal merupakan hasil pemikiran, gagasan dan konsep, baik seseorang maupun sekelompok orang yang hidup dalam sebuah lingkungan budaya. Pakaian juga merupakan kebutuhan pokok manusia.

Palembang mempunyai beberapa pakaian adat yaitu, di antaranya, aesan gede dan pak sangkong. Pakaian adat adalah lambang kebesaran sekaligus merefleksikan falsafah dan pandangan hidup, konsep dan gagasan serta tanggung jawab terutama pemimpinan suatu etnik, sub etnik. Secara fungsional, pakaian adat itu hanya (boleh) dipakai pada upacara tertentu (Mutia, 1996: 19).

Aesan Gede dan Pak sangkong merupakan pakaian adat yang dipakai oleh pengantin ketika acara resepsi pernikahan di Palembang. Pakaian ini dipakai saat upacara adat perkawinan di Palembang, yaitu "penganten munggah". Setelah melewati beberapa tata upacara adat perkawinan di Palembang, seperti: madik (memilih calon pengantin), menyenggung (memantapkan pilihan), meminang (melamar), berasan, memutus kato, mengantar uang belanja, bedandan, akad nikah, mengarak pacar, munggah, upacara di ruangan gegajah, menjenguk pengantin, menjemput pengatin, berkeramas (mandi simbur), mempertemukan pengantin, syukuran, nyanjoke pengantin dan pengantin tandang (Saragih, 2001: 24). Munggah adalah salah satu upacara adat perkawinan yang merupakan puncak dari pada upacara perkawinan seluruhnya (Saramat, 1997: 93). Pada acara munggah inilah aesan gede dan pak sangkong dipakai dalam acara tersebut. 
Menurut Ali Hanafiah, pakaian adat pernikahan Palembang ini mendapat pengaruh dari kebudayaan luar atau asing (Hanafiah, Wawancara Pribadi, 6 Juni 2016). Masuknya kebudayaan luar atau asing ini juga dipengaruhi oleh letak geografis Palembang yang pada zaman Kerajaan Sriwijaya terdapat pelabuhan besar tempat singgahnya para pedagang dari luar termasuk Jawa, Cina dan Arab. Dengan singgahnya orang-orang luar di Palembang ini menyebabkan kebudayaan Palembang mendapat pengaruh yang sangat besar dari kebudayaan luar tersebut. Termasuk pakaian adat pernikahan Palembang yang mendapat pengaruh tersebut.

Pakaian adat pernikahan Palembang, yakni aesan gede dan pak sangkong terdapat bagian bagian mulai dari yang pokok sampai aksesoris pelengkapnya. Yang kesemuanya memiliki pesan tersirat atau memiliki makna-makna simbol dari tiap-tiap bagian dari pakaian adat pernikahan Palembang.

\section{Makna Simbol dalam Aesan Gede dan Pak Sangkong Pakaian Adat Pernikahan Palembang}

Pakaian adat pernikahan Palembang baik aesan gede dan pak sangkong, dari masing-masing bagian mempunyai makna simbol. Makna simbol aesan gede dan pak sangkong ini akan diuraikan lebih lanjut yaitu, sebagai berikut:

\section{Kain Songket}

Kain songket pada pakaian adat pernikahan di Palembang yang sering dipakai memiliki motif geometris abstrak murni, yaitu perulangan garis zig-zag. Motif zigzag disebut juga motif tumpal. Dalam sejarah, motif geometris merupakan motif tertua dalam ornamen karena sudah dikenal sejak zaman prasejarah. Motif geometris menggunakan unsur-unsur rupa seperti garis dan bidang yang pada umumnya bersifat abstrak artinya bentuknya tak dapat dikenali sebagai bentuk objek-objek alam (Sunaryo, 2009: 19).

Seperti yang terdapat di dalam buku Ragam-ragam Perhiasan Indonesia disebutkan bahwa pemakaian motif tumpal ini yang paling terkenal adalah terdapat pada batik dan tenun (Hoop, 1949: 28). Motif tumpal pada kain songket ini yang terbentuk dari motif garis zig-zag dipadu dan didampingkan dengan garis lurus. Ini merupakan simbol keramahan dan saling menghormati sesama manusia dan menjaga ketertiban (Sunaryo, 2009: 32). Dengan demikian, makna simbol yang terdapat pada kain songket ini merupakan keramahan, ketertiban dan saling menghormati pada masyarakat Palembang.

\section{Celano Sutra}

Celano sutra ini ialah celana panjang yang berbahan sutra. Pada bagian bawah celana terdapat bordiran yang berbentuk bunga yang mempunyai tangkai yang panjang atau menjalar. Di dalam buku Ornamen Nusantara (Kajian Khusus tentang Ornamen Indonesia), bentuk bunga yang mempunyai tangkai yang panjang atau menjalar ini 
disebut motif sulur. Motif sulur ialah gubahan tumbuhtumbuhan yang menjalar (Sunaryo, 2009: 159). Motif sulur ini sebagai simbol kebahagian dan kemujuran serta melambangkan harapan masa depan yang lebih baik.

Namun, pada buku Sejarah Kebudayaan Islam Seni Rupa dan Desain, motif sulur pada masa Kerajaan Minangkabau/ Pagaruyung disebut motif hias Aka Bapilin. Motif hias Aka Bapilin ini dibuat lebih abstrak mengikuti tradisi Islam. Motif hias aka bapilin dapat diartikan yaitu aka yang berarti akar dan akal. Jadi, motif hias aka bapilin ini memiliki makna simbol bahwa mentalitas orang Minangkabau yang sangat gigih dalam menjalani kehidupan dimana pun berada (Sedyawati, 2009: 72-73). Dengan ini, kepada pengantin agar setelah pernikahan akan mendapatkan kebahagian dan kemujuran serta bisa menjalani kehidupan yang lebih baik lagi dimana pun.

\section{Dodot}

Sama seperti kain songket di atas, dodot juga mempunyai motif tumpal dengan garis zig-zag. Bedanya, motif tumpal pada dodot ini terdapat pada kanan dan kiri. Ini menyimbolkan bahwasanya kedua pengantin Palembang sebagai makhluk sosial, harus ramah, tidak boleh sombong, harus saling menghormati sesama manusia dan menjaga ketertiban.

\section{Jubah}

Jubah merupakan akulturasi dari Arab. Jubah ini merupakan baju panjang yang bertaburkan bunga-bunga. Bunga-bunga yang terdapat pada jubah ini seperti bunga teratai yang sedang mengapung di atas air. Teratai adalah motif yang paling umum digunakan pada seni rupa Hindu Budha. Teratai melambangkan tempat kedudukan divinitas tertinggi, kelahiran alam semesta, kelahiran Budha, kebenaran sejati, tempat kedudukan energy yang suci dan vital (dalam diri seseorang yang mempraktikkan yoga) dan cinta kasih (Sedyawanti, 2009: 48). Motif hias bunga teratai simbol dari kemurnian dan kesucian (Sedyawanti, 2009: 154). Maksud dari baju yang bertaburkan bungabunga ialah bahwasanya pengantin laki-laki sedang merasakan kebahagian atau kesenangan karena telah menjadi pasangan suami istri.

\section{Rompi}

Rompi pada pakaian adat pernikahan Palembang ini sebagai pakaian dalam pengantin laki-laki pada pakaian adat pak sangkong. Pada rompi ini terdapat motif tunas tumbuhan pada bagian dada yang membentuk pola geometris yaitu garis zig-zag. Motif tunas tumbuhan merupakan simbol bahwa agar manusia hendaknya berguna bagi manusia lainnya (Sunaryo, 2009: 32). Selanjutnya, garis zig zag seperti yang sudah dijelaskan di atas merupakan simbol dari keramahan, ketertiban dan saling menghormati sesama manusia. Jadi, rompi merupakan simbol dari kehidupan yang baru kepada pengantin agar supaya berguna dan saling menjaga kerukunan dalam menjalankan kehidupan rumah tangga. 
Baju kurung merupakan pengaruh dari Melayu-Islam yang dipakai oleh pengantin perempuan. Motif pada baju ini sama seperti halnya pada jubah yang dikenakan oleh pengantin laki-laki yaitu bertabur bunga-bunga. Menyimbolkan bahwa pengantin perempuan juga merasakan kebahagian dan kesenangan atas pernikahan keduanya.

\section{$7 \quad$ Kesuhun Pengantin Laki-laki}

Kesuhun pengantin laki-laki. Motif hias yang terdapat pada kesuhun laki-laki ini ada dua, yaitu: motif hias cemen dan motif hias bunga. Motif hias cemen ialah motif hias untuk laki-laki. Cemen adalah kemaluan laki-laki (Sunaryo, 2009: 54). Seorang laki-laki mempunyai tugas pokok melindungi keluarga dan masyarakat. Motif hias cemen ini simbol bahwa seorang laki-laki harus mempunyai sifat berani. Berani dalam keluarga dan masyarakat.

Yang kedua ialah motif hias bunga yang terdapat pada kesuhun ini merupakan motif hias bunga mawar. Motif hias bunga mawar disebutkan merupakan lambang kesucian dan keangungan (Toekio, 2000: 81). Jadi, kesuhun pengantin laki-laki ini merupakan simbol dari keagungan dan keberanian dalam keluarga.

\section{Kesuhun Pengantin Perempuan}

Kesuhun pengantin perempuan. Motif hias yang terdapat disini ialah motif cen dan motif hias bunga. Motif cen yang berarti motif kelamin wanita sebagai jalan kelahiran. Motif cen ini disimbolkan sebagai asal kehidupan dan dianggap sebagai penghormatan dan penghargaan kepada wanita sebagai pusat kehidupan (Sedyawanti, 2009: 54). Perempuan dalam kehidupan haruslah dihormati dan diberi penghargaan karena merupakan pusat kehidupan.

Motif hias bunga pada kesuhun ini yaitu bunga mawar. Bunga mawar dianggap sebagai simbol matahari dan bulan. Di daerah Kalimantan Barat, motif bunga mawar pada kain songket melambangkan kekeluargaan (Sunaryo, 2009: 155). Jadi, kesuhun pengantin perempuan simbol dari perempuan mempunyai sifat keibuan, kelembutan dan mempunyai rasa kekeluargaan.

\section{Tebeng Malu}

Penutup bagian samping kepala yang sering disebut tebeng malu. Sabuk ini dipasang dengan tujuan agar pengantin tidak saling lirik. Dalam adat Palembang, adalah tabu bagi mempelai untuk saling lirik, apalagi saling pandang dan berbicara, selama prosesi di atas puade (pelaminan) berlangsung (Syarofie, 2007: 40). 
Eka Hikmawati

Makna Simbol dalam Asean Gede dan Pak Sangkong

Pakaian Adat Pernikahan Palembang

\section{Pending}

Pending ialah ikat pinggang. Pada ikat pinggang terdapat motif tumbuhan yang menjalar. Makna motif tumbuhan yang menjalar ini yaitu, sebagai simbol harapan masa depan yang lebih baik (Sunaryo, 2009: 159). Dengan demikian, Pending ini mempunyai makna simbol bahwa perempuan dan laki-laki siap untuk menjalani kehidupan atau sebagai simbol pengukuhan kehidupan.

\section{Selendang Pelangi}

Selendang pelangi yang mempunyai motif garis geometris yaitu garis lengkung dan dipadu dengan garis horizontal. Garis lengkung merupakan simbol dari kebahagian atau kegembiraan. Sedangkan, garis horizontal simbol dari ketenangan (Toekio, 2000: 29). Jadi, selendang pelangi mempunyai makna simbol bahwa orang Palembang merasakan kebahagiaan dan ketenangan dalam kehidupan bermasyarakat.

\section{Kelapo Setandan}

Kelapo setandan terdapat hiasan bunga teratai yang mempunyai tangkai. Hiasan bungai teratai di keraton Cirebon dianggap sebagai simbol kebesaran dalam ketatanegaraan. Dalam kepercayaan Budha, bunga teratai juga simbol dari kemurnian karena muncul tidak tercela meskipun dari dalam lumpur (Sunaryo, 2009: 154). Pada pelengkap pakaian adat pernikahan Palembang terdapat tujuh tangkai bunga teratai yang artinya pikiran perasaan, penglihatan, kebiksanaan, kesadaran, kebesaran dan kemurnian.

\section{Ketu}

Ketu adalah semacam mahkota yang berbentuk topi. Dibagian depan ketu ini terdapat hiasan geometris yang membentuk seperti objek-objek alam. Di bagian samping terdapat hiasan bunga cempaka dan bagian atas ketu ini juga terlihat seperti taburan bunga teratai.

Hiasan geogmetris yang membentuk objek alam mempunyai makna simbol dari rasa keindahan dan kecintaan. Serta, hiasan bunga cempaka dan teratai menyimbolkan keagungan dan kesucian (Toekio, 2000: 80-81). Jadi, ketu ini simbol dari laki-laki Palembang sebagai pemimpin yang agung dan mempunyai kecintaan terhadap daerahnya dan keluarga.

\section{Mahkota Pak Sangkong}

Mahkota putri yaitu pak sangkong ini dipakai dikepala bagian kening yang diikatkan kebelangkang. Pada mahkota ini terdapat motif hias bunga teratai dan setangkai bunga mawar, selanjutnya terdapat motif dasar berbentuk lingkaran. Bunga teratai seperti yang telah dijelaskan di atas merupakan simbol dari kesucian dan bunga 
mawar merupakan simbol dari kekeluargaan dan merupakan simbol dari matahari dan bulan (Sunaryo, 2009: 155).

Motif hias berbentuk lingkaran simbol dari benda angkasa matahari yang bermaksud sebagai kepercayaan terhadap Tuhan sang pencipta dan pengatur segalanya (Sunaryo, 2009: 33). Mahkota pak sangkong ini merupakan simbol dari kesucian dan kepercayaan terhadap Tuhan.

\section{Gandek}

Sama seperti mahkota pak sangkong, gandek juga dipakai dikepala bagian kening, bedanya gandek ini dipakai terlebih dahulu dibandingkan mahkota pak sangkong. Gandek terdapat motif hias bunga teratai. Pada pakaian adat pengantin Kayuagung, gandek ini bermakna simbol yang berarti perempuan terkesan pemikir. Jadi, gandek merupakan simbol dari kesucian dari memikiran perempuan Palembang.

\section{Cempako}

Cempako ini ialah bunga cempaka. Cempako ini merupakan motif hias bunga yang mensimbolkan keindahan dan keanggunan (Syarofie, 2007: 35). Cempako ini mempunyai makna simbol bahwa orang Palembang harus menjaga keindahan perilakunya.

\section{Sumping}

Sumping seperti yang telah dijelaskan di atas ialah bunga untuk menutupi telinga. Bunga mempunyai makna simbol keindahan. Sumping mempunyai makna simbol bahwa dalam kehidupan harus mendengarkan segala hal yang baik-baik.

\section{Gelung Malang}

Gelung malang ialah rambut yang digelung yang member kesan kerapian. Gelung malang ini membentuk garis horizontal yang melengkung. Seperti penjelasan di atas simbol dari garis horizontal yang melengkung ialah rasa ketenangan dan kegembiraan (Toekio, 2000: 29). Dengan demikian, gelung malang mempunyai makna simbol bahwa perempuan Palembang ialah sosok yang anggun yang mengutamakan kerapian dan mempunyai rasa ketenangan dalam menghadapi sesuatu.

\section{Kembang Ure}

Kembang Ure berbahan pandan dan bunga warna-warni yang dipakai di kepala bagian belakang yang menyerupai atau bagaikan rambut yang terurai. Kembang ure mempunyai makna simbol keanggunan seorang perempuan (Syarofie, 2007: 35). Kembang ure simbol bahwa perempuan Palembang adalah sosok yang anggun dan dapat memberikan warna tersendiri bagi keluarga. 
Eka Hikmawati

Makna Simbol dalam Asean Gede dan Pak Sangkong

Pakaian Adat Pernikahan Palembang

\section{Terate}

Terate adalah penutup dada. Motif hias yang dipakai ialah bunga teratai sebagai penutup dada. Bunga teratai merupakan simbol dari kesucian dan keangungan (Toekio, 2000: 81). Terate ini merupakan simbol dari orang Palembang, baik laki-laki dan perempuan harus mempunyai rasa kesabaran dan ketabahan hati dalam hal apapun.

\section{Kalung Tapak Jajo}

Kalung tapak jajo ini di ujung kalungnya terdapat seperti kerbau. Motif hias kerbau ini juga dapat ditemukan pada motif hias orang Toraja (Hoop, 1949: 136). Dijelaskan bahwa kerbau merupakan binatang ternak dan bermanfaat untuk membantu dalam mengolah lahan pertanian (Sunaryo, 2009: 122). Motif kerbau ini dalam ornament nusantara umumnya digunakan sebagai lambang kesuburan dan dipandang sebagai penolak yang jahat (Sunaryo, 2009: 122).

\section{Selempang Sawit}

Selempang sawit merupakan selempang yang diselempangkan di bahu, baik lakilaki maupun perempuan. Ini mempunyai makna simbol bahwa laki-laki dan perempuan harus sejajar, tidak ada yang di atas dan tidak ada yang merasa di bawah.

\section{Kecak Bahu}

Kecak bahu merupakan hiasan bahu. Kecak bahu mempunyai makna simbol bahwa laki-laki dan perempuan Palembang harus mempunyai kekuatan dalam menjalani kehidupan.

\section{Gelang}

Gelang ini merupakan simbol dari keanggunan (Syarofie, 2007: 35).

\section{Cincin}

Cincin mempunyai makna simbol bahwa perempuan sudah menikah. Tetapi, zaman sekarang makna dari cincin sudah luas ada yang hanya sebagai hiasan semata.

\section{Setangan}

Setangan ini berbentuk persegi panjang yang merupakan gabungan garis vertikal dan horizontal, serta dibagian depan terdapat motif geometri yaitu garis zigzag. Makna Simbol vertikal dan horinzontal yaitu ketegaran, kemuliaan dan Ketenangan (Toekio, 2000: 29). Garis zig-zag merupakan simbol dari semangat. Jadi, setangan merupakan simbol ketegaran dan ketenangan hidup. 


\section{Cenela}

Cenele yaitu sandal. Cenela mempunyai makna simbol bahwa dalam kehidupan dalam melangkah harus mempunyai pelindung diri yaitu agama.

\section{Unsur-unsur yang Terkandung pada Pakaian Adat Aesan Gede dan Pak Sangkong}

Terdapat tiga unsur yang terdapat pada pakaian adat pernikahan Palembang, yakni aesan gede dan pak sangkong yaitu, unsur keindahan (estetika), dan unsur kesopana (etika).

\section{Unsur Keindahan (Estetika)}

Kesenian merupakan bagiian dari budaya suatu masyarakat yang tak dapat dipisahkan dari kehidupan masyarakat itu sendiri. ia lahir dan keberadaannya sesuai dengan fitrah manusia yang selalu mencintai keindahan (estetika). Keberadaan kesenian dan daya cipta seni, termasuk peninggalan budaya dalam suatu masyarakat, menjadi simbol tingkat perkembangan peradaban suatu masyarakat. Daya cipta seni ari segi wujudnya dapat dibagi dua, yaitu daya cipta seni yang berwujud konkretkebendaan, seperti candi-candi, benda-benda peninggalan sejarah, seni rupa. Yang kedua yaitu daya dipta seni yang berwujud simbol. Hal ini hanya dapat dilihat dan dirasakan, seperti taritarian, pantun-pantun, karya sastra, acara-acara adat, pertunjukan dan lain-lain (Direktorat Sejarah dan Nilai Tradisional, 1992: 165-166).

Nilai estetika dari suatu karya seni adalah berupa nilai keindahan yang melekat pada karya seni itu sendiri. Tentu saja, penilaian tentang indah tidaknya suatu karya seni tergantung setiap orang, namun yang perlu kita catat bahwa masyarakat penciptanya atau bangsa dimana karya seni itu dilahirkan masih akan tetap menganggapnya sebagai sesuatu yang indah apalagi upaya penghayatan terhadap nilai-nilai budaya tetap ditanamkan dalam masyarakat dari generasi ke generasi (Direktorat Sejarah dan Nilai Tradisional, 1992: 165-166).

Keindahan berasal dari kata indah yang berarti bagus, permai, cantik, molek dan sebagainya. Benda yang mengandung keindahan ialah segala hasil seni dan alam semesta ciptaan tuhan ini. Seperti pada pakaian adat pernikahan Palembang yang merupakan daya cipta seni yang berwujud konkret atau kebendaan, pakaian adat pernikahan ini mempunyai nilai keindahan di setiap sudut dari aesan gede dan pak sangkong. Penciptaannya sendiri pun harus mempunyai rasa seni atau rasa estetika tersendiri untuk menciptakan sebuah karya dalam bentuk pakaian adat.

\section{Unsur Kesopanan (Etika)}

Etika berasal dari bahasa Yunani Kuno ethikos yang berarti timbul dari kebiasaan. Sudut pandang etika ialah tingkah laku manusia dari sudut baik dan buruk terhadap perbuatan manusia. Etika dibagi kedalam dua jenis yakni, etika filosifis dan etika teologis. Dalam hal ini cara berpakaian terutama pakaian adat aesan gede dan pak 
sangkong merupakan etika teologis. Yang perlu diingat pada etika teologis ini adalah pertama, etika teologis bukan hanya milik agama tertentu, melainkan setiap agama dapat memilikietika teologisnya masing-masing. Kedua, etika teologis merupakan bagian dari etika secara umum. Etika teologis merupakan etika dari setiap agama berdasarkan apa yang diyakini dan menjadi sistem nilai-nilai yang dianutnya (Madewa, 2013). Pada penelitian terdapat dua etika teologis yakni, Hindu-Budha dan Islam.

Unsur Hindu Budha sendiri terkandung pada pakaian adat aesan gede. Aesan gede yang telah dijelaskan sebelumnya yaitu diduga berasal dari Kerajaan Sriwijaya. Kepercayaan Kerajaan Sriwijaya yaitu Hindu-Budha (Syarofie, 2013: 12), ini terbukti bahwasanya Bukit Siguntang di kawasan Bukit Kecil merupakan tempat pemujaan atau tempat beribadah umat Hindu Budha pada saat itu. Pemakaian dodot pada aesan gede sebuah akulturasi dari Jawa yang sesuai dengan kepercayaan pada saat itu yaitu Hindu Budha.

Berbeda dengan pakaian adat pak sangkong yang merupakan pakaian adat pernikahan Palembang yang didalamnya terkandung unsur Islam. Pemakaian baju kurung yang tertutup pada pengantin perempuan merupakan salah satu syariat Islam untuk kaum muslimah. Seperti yang terkandung dalam firman Allah Swt. dalam surat Al- Ahzab ayat 59.

Yang artinya: "Hai Nabi, Katakanlah kepada isteri-isterimu, anak-anak perempuanmu dan isteri-isteri orang mukmin: "Hendaklah mereka mengulurkan jilbabnya ke seluruh tubuh mereka". yang demikian itu supaya mereka lebih mudah untuk dikenal, karena itu mereka tidak di ganggu. Dan Allah adalah Maha Pengampun lagi Maha Penyayang.” (Qs: Al-Ahzab: 59)

Selain baju kurung, pemakaian ketu dan jubah pada pengantin laki-laki juga merupakan kebiasaan orang-orang Islam Arab yang diakulturasikan menjadi kebudayaan Palembang khususnya pada pakaian adat pak sangkong ini.

\section{Kesimpulan}

Dari uraian pada pembahasan di atas, dapat disimpulkan bahwa: Proses akulturasi tidak menimbulkan hilangnya kepribadian asli kedua masyarakat itu, namun hanya unsur-unsur tertentu saja yang melebur. Bagian-bagian dari masyarakat penerima unsur-unsur kebudayaan asing terlebih dahulu yaitu, para penguasa, yang pada saat itu menjadi penguasa di Palembang, karena orang-orang Jawa, Cina dan Arab menjalin hubungan kerjasama dengan para penguasa di Palembang. Sementara itu, rakyat biasa belum banyak terkena pengaruh dari kebudayaan Jawa, Cina dan Arab tersebut.

Simbol-simbol yang terkandung dalam aesan gede dan pak sangkong sebagai berikut: bahwasanya pada pakaian adat aesan gede dan pak sangkong ini Merupakan simbol kebaikan kehidupan di dunia dan akhirat. Kebaikan di dunia yaitu agar setelah 
Eka Hikmawati

Makna Simbol dalam Asean Gede dan Pak Sangkong

Pakaian Adat Pernikahan Palembang

pernikahan akan mendapatkan kebahagian dan kemujuran. Juga, terdapat simbol dalam berperilaku yaitu, ramah, tertib dan saling menghormati. 
Eka Hikmawati

Makna Simbol dalam Asean Gede dan Pak Sangkong

Pakaian Adat Pernikahan Palembang

\section{Daftar Pustaka}

Direktorat Sejarah dan Nilai Tradisional. 1992. Kongres Kebudayaan 1991: Daya Cipta dan Perkembangan Budaya. Jakarta: Departemen Pendidikan dan Kebudayaan.

Hanafiah, Ali. Wawancara. Palembang, 06 Juni 2014.

Hoop, Van Der. 1949. Ragam-ragam Perhiasan Indonesia. Batavia: Bataviaasch Genootschap.

Koentjaraningrat. 1996. Pengantar Antropologi I. Jakarta: Rineka Cipta.

M, Soegeng Toekio. 2000. Mengenal Ragam Hias Indonesia. Bandung: Angkasa.

Madewa, Surya. 2013. "Etika", Artikel di Akses pada 20 Mei 2015 dari http://suryamadewa.blogspot.in/2013/03/etika_7249.html?m=1

Mutia, Riza. 1996. Pakaian Penghulu Minangkabau. Sumatera Barat: Proyek Pembinaan Permuseuman.

Rosyadi, Ulin Nuha. 2012. Kekayaan Seni Budaya Bangsaku. Bekasi: Aranca Pratama.

Saragih, Meriati S. dkk. 2001. Perlengkapan Upacara Daur Hidup Masyarakat Palembang Koleksi Museum Balap utra Dewa. Palembang: Dinas Pendidikan Nasional Propinsi Sumatera Selatan.

Saramat, Darwis. 1997. Bunga Rampai Adat-Istiadat. Jakarta: Pusat Penelitian Sejah dan Budaya Departemen Pendidikan dan Kebudayaan Jakarta.

Sedyawati, Edi dkk. 2009. Sejarah Kebudayaan Indonesia Seni Rupa dan Desain. Jakarta: Rajawali Pers.

Sunaryo, Aryo. 2009. Ornamen Nusantara: Kajian Khusus tentang Ornamen Indonesia. Semarang: Dahara Prize.

Syarofie, Yudhy. 2007. Songket Palembang: Nilai Filosofis, Jejak Sejarah, dan Tradisi. Palembang: Dinas Pendidikan Pemerintah Propinsi Sumatera Selatan.

Syarofie, Yudhy. 2013. Pakaian Adat Pengantin di Sumatera Selata: Palembang, OKI dan OKU Selatan. Palembang: Dinas Pendidikan Pemerintah Propinsi Sumatera Selatan. 